\title{
THE UNPRECEDENTED CONTEXTUAL INTERPRETATION OF THE MISOGYNIC HADITTH AT THE REFORMIST PERSIS PESANTREN IN BANGIL'
}

\author{
Masruhan | UIN Sunan Ampel Surabaya - Indonesia \\ masruhan_munas@gmail.com
}

\begin{abstract}
The contextual interpretation of the hadith is interpretation of hadith in accordance with the background, situation, condition, and the position of Prophet Muhammad in his utterances, deeds, and his provisions in his status as the Messenger of God and relate them with the current context. Some 'ulamā' of the so-called Reformist Pesantren in Indonesia, 'ulamā' of Persis Pesantren in Bangil have interpreted misogynic hadiths differently. Some interpret contextually to locate its relevance in contemporary situation, while the rest of 'ulama' in that pesantren deny the existence of the idea of misogyny in hadith and thus interpreted the hadiths textually. This article discusses the method, approach, typology in interpreting hadith employed by those 'ulamā'. It turns out that the interpretation of misogynic hadiths at the reformist Persis Pesantren In Bangil could be classified into two approaches; contextual-hermeneutic and metaphoric approach and textual and literal on the other. The two approaches are fluid considering the hadith under discussion.
\end{abstract}

Keywords: Misogynic hadith, reformist pesantren, contextual interpretation

\section{Introduction}

The contextual interpretation on normative Islam, including hadith, is found among Muslim reformists, including hadith with misogynic tendency. The idea of misogynic hadith was originally popularized by Fatima Mernissi, a feminist from Morocco and an anthropologist by training. ${ }^{2}$ Many hadith that according to feminists contain misogynic

1 This article comes to its accomplished version under the auspices of the UIN Sunan Ampel Surabaya. I herewith send my warmest gratitude to who have read the earlier form of the paper including Akh. Muzakki and Asfa Widiyanto.

2 Fatima Mernissi, Perempuan dalam Islam (Bandung: Penerbit Pustaka, 1994), a translation from Fatima Mernissi's work, Women in Islam: A Historical and Theological 
ideas, referring that many hadiths convey in its meaning aversion toward women. ${ }^{3}$ After her, misogynic hadith and its interpretation has already been discussed by many contemporary Indonesian Muslims. Majority of them are against the textual interpretation, as Hamim Ilyas, Muhammad Sodik, Inayah Rohmaniyah, ${ }^{4}$ Siti Musdah Mulia, ${ }^{5}$ Marhumah, ${ }^{6}$ Muhamad Rofiq, ${ }^{7}$ Muhammad Rikza Muqtada, ${ }^{8}$ Hasani Ahmad Said, ${ }^{9}$ Ahmad Khozin. ${ }^{10}$ In addition to many Muslim feminists who write many about the matter, Muslims elsewhere also concern about this issue, like Hidayet Sefkatli Tuksal, ${ }^{11}$ Nur Saadah Khair and Nurdina Dahlan. ${ }^{12}$

Enquiry (USA: Oxford, 1991) revised dissertation in French published in English: Beyond The Veil: Male-Female Dynamics in Modern Muslim Society and translated Seks dan Kekuasaan (n.pl: Penerbit al-Fikr, 1975).

3 Among Muslim feminists are Fatima Mernissi (Morocco), Riffat Hassan (Pakistan), Asghar Ali Engineer (South Africa) dan Aminah Wadud Muhsin (the US), Asma Barlas (Pakistan-the US), Ziba Mir-Hosseini (Iran), Kamla Bhasin dan Nighat Said Khan (South Asia), Mansour Fakih (Indonesia), Siti Musdah Mulia (Indonesia), and Syafiq Hasyim (Indonesia).

${ }^{4}$ Hamim Ilyas; Mochamad Sodik; Inayah Rohmaniyah, Perempuan tertindas?: Kajian Hadis-hadis 'misoginis' (Yogyakarta: eLSAQ Press and Pusat Studi Wanita (PSW), UIN Sunan Kalijaga, 2005).

5 Siti Musdah Mulia, Muslimah Reformis (Bandung: Mizan, 2005).

6 Marhumah, "The roots of gender bias: misogynist hadiths in pesantrens," Indonesian Journal of Islam and Muslim Societies, 5, 2 (2015).

7 Muhamad Rofiq, "Memahami Hadis-Hadis Misoginis Perspektif Maqasid Syariah: Studi Hadis yang Menyamakan Antara Keledai, Anjing dan Perempuan," Ilmu-Ilmu Ushuluddin, 16, 01 (April 2015), p. 14.

8 Muhammad Rikza Muqtada, "Kritik Nalar Hadis Misoginis" Musâwa, 13, 2 (Desember 2014).

9 Hasani Ahmad Said, "Hadis-Hadis Misoginis: Wacana Pemahaman Hadis, Menggali Akar Sosio-Kultural," al-D ₹ikera, 6, 1 (January 2012), p. 16.

10 Ahmad Khozin, Pemahaman Hadis Misoginis pada Kitab Uqudul Lujayn Pondok Pesantren An Nur Klego Candirejo Tambang Kab. Semarang (Unpublished Master thesis, IAIN Salatiga, 2017).

11 Hidayet Şefkatli Tuksal, "Misogynistic Reports in the Hadith Literature," Ednan Aslan and Marcia Hermansen, Muslima Theology: The Voices of Muslim Women Theologians (Frankfurt: Peter Lang GmbH, 2013).

12 Nur Saadah Khair and Nurdina Dahlan, "The Debate on Anti-Woman Discourse in the Hadith Literature," Journal of Hadith Studies, 2, 1 (June 2017). 
On the contrary, earlier Muslim reformists such as Muhammad bin 'Abd al-Wahab (d. 1792). ${ }^{13}$ as well as their contemporary followers like Abd al-Aziz ibn Baz and Salih ibn Uthaymin ${ }^{14}$ tended to interpret religious text including misogynic hadith by way of their wording and text, The principle approach taken by them in their interpretation of the prophet's hadith is textual without takwill, based on philology and orthodox. ${ }^{15}$ Their insistence on this textual approach originates to their belief that Muslims had mixed Islam with foreign elements that were harmful for Islamic belief. Therefore, it needed purification, which in turn gave rise to the slogan of "Back to Islam". This so called reformism urged Islam to be freed from superstition, innovation and idolatry. It also stayed out from finality and conclusiveness of Islamic jurisprudence compiled by four Sunni schools of law. Thus, they encourage ijtihād if necessary. Therefore, the typology which is used in their interpretation of hadith is textual, including those considered to be misogynic hadiths. Therefore, there are at least two approach in hadith interpretation, including misogynic hadiths; contextual and contextual.

This article will focus on the contextual interpretation of misogynic hadith by Muslim reformists in Indonesia. As one of the representatives of this approach, 'ulamā' of Persis Pesantren in Bangil Pasuruan East Java will be taken as the subject to this writing. They too, display the two approaches in their interpretation of misogynic hadiths. Some 'ulamā' of Persis Pesantren in Bangil prefer to bring the concept of egalitarian and justice in their interpretation of misogynic hadith. This kind of hadith ${ }^{16}$ needs to be reinterpreted to bring a new light on the understanding that fits contemporary situation. This reinterpretation should be understood hand by hand with other relevant hadiths to get a comprehensive understanding without

13 Noor al-Din Atabik, "Pendekatan Kaum Modernis Terhadap Studi Hadis," https://jurnalulumulhadis.blogspot.com/ 2014/02/pendekatan-kaum-modernis-terhadap-studi.html/, accessed on September 21, 2019.

14 Read one of his sermons entitled "women: the greatest Temptation," https://abdurrahman.org/2016/10/04/women-the-greatest-temptation/, accessed on October 15, 2019.

15 Atabik, "Pendekatan Kaum Modernis.

16 The hadith on this matter is about prohibition of women from becoming leader. See Al-Bukhari, Shabih al-Bukhari (Semarang: Thaha Putra, 1401/1981), Vol. 8, p. 97. 
neglecting the fundamental value of the hadith, the spirit of the prophet in his attitude and substantial value of prophet's struggle to stand for justice and equality. Meanwhile, the rest of them remain consistent in interpreting hadith textually since they believe that it is the most immediate approach to the truth. Textual interpretation is also considered the authentic way without any intermediary of past 'ulamā'. Indeed, Persis is known for this feature. ${ }^{17}$

This article will focus on the contextual approach taken by some 'ulamā' of Persis Pesantren in their understanding of misogynic hadith. It is argued that this approach is unprecedented, considering their puritanical and textual nature. In the introduction, this article will describe religious overview of Persatuan Islam (Persis), an Islamic organization established in Bandung in 1923. In sequence, the discussion moves on to describe how the 'ulamă' of Persis Pesantren in their interpretation of misogynic hadith including method, approach, and product of interpretation. Some hadith will be highlighted for this purpose.

\section{Persatuan Islam, A. Hassan and Islamic Standpoint}

Among the religious community organizations in Indonesia that give much attention to the hadith is the Persatuan Islam (Persis). Persis established on September 12, 1923 in Bandung West Java by by the Tadārūs group. ${ }^{18}$ Tadārūs once was an informal discussion group in Bandung that discussed Islam. The members of this group were merchants born in Sumatera who migrated to Bandung. Two leading in this discussion, Hadji Zamzam and Hadji Muhammad Junus, once spent a couple of years studying in the Middle East. ${ }^{19}$ The topics that led to the creation of Persatuan was a support of reformist ideas which had been circulated in Sumatera and certain part of Java and its reaction from the established Islamic tradition. However, in its initial period, the reformist ideas was not much discussed because the Persis

\footnotetext{
17 M. Arfan Mu'ammar, "Puritanism of Islam in Islamic Boarding School (Pesantren): Models of Religious Understanding in Puritan Pesantren in East Java," Jurnal Reflektika, 12, 2 (July-December 2017), pp. 142-143.

18 Deliar Noer, Gerakan Moderen Islam di Indonesia 1900-1942 (Jakarta: LP3ES, 1985), p. 99.

19 Howard M. Federspiel, Islam and Ideology in the Emerging Indonesian State: The Persatuan Islam (Persis), 1923 to 1957 (Leiden: Brill, 2001) p. 84.
} 
membership of the time comprised of modernist Muslims as well as Muslims with traditionalist point of view. It was until 1926 when Ahmad Hassan joined that Persis proclaimed its reformist identity. ${ }^{20}$ From then on, Persis had two agendas, purifying Islam from unorthodox innovation and adapting Islamic teachings into contemporary conditions. ${ }^{21}$ These two identities are Persis identity, they are not separated. Admittedly, some memberships or figures put more emphasis on the purification agenda, while the others might fight for modernization or contextualization efforts. Nevertheless, purification tendency is stronger.

Surely, both two agendas were apparent in its emergence in the pre-independence period. Its beginning stemmed from concern about unfortunate condition of the Muslims in Indonesia both at the level of ideas and in practice. ${ }^{22}$ Persis perceived itself as is the answer to the challenges of the condition of Muslims who are immersed in stagnation, mired in an excessive life of mysticism, the flourishing of khuräfät (heresy), takbayyūl (superstition), and shirk (idolatry). Furthermore, it saw how Muslims were shackled by the Dutch colonial occupation which tried to extinguish the light of Islam. ${ }^{23}$ Such a situation inspired the emergence of an Islamic "reformism" movement, influencing the Indonesian Islamic community to reform their Islamic thought. Surely, the Persis reform movement was also stimulated by the writings of Muhammad Abduh in the Al-Manar magazine, 'al-Islam mabjūb bi al-Muslimin' ([the greatness of] Islam is covered by [bad things] of muslims). This paper affected the religious emotion of the pioneers of the Persis organization at the time who wanted to live according to the al-Qur'an and Hadith. After the joining of Ahmad Hassan (d. 1958) in 1926, Mohammad Natsir (d. 1993) joined the bandwagon of Persis in 1927 who later became political activist and ideologist of Persis, ${ }^{24}$

\footnotetext{
20 Ibid., p. 85.

21 Ibid., p. 87.

22 Imron Rosyadi, "Metode Penetapan Hukum dewan Hisbah Persis," Subuf, 19, 2 (2007).

23 Dadan Wildan, Da'i Yang Politisi (Bandung: Rosda Karya, 1997), p. 3.

24 Ibid., p. 97.
} 
Persis was seen as a very puritan, aggressive, and extreme in its approach, particularly in its heyday of the 1920s, 1930s, and 1950s. ${ }^{25}$

This organization, although relatively small, has wide influence among modern Muslims in the archipelago through publication and writings. ${ }^{26}$ Its role is not seen from the small scale of the organization, but rather the discourse of religious thought which is a catalyst characteristic of Persis. Its organizational statutes states that Persis's vision is "the realization of Muslim community based on the al-Qur'an and Sunnah." Its objectives are; (1) to bring Muslims back to the alQur'an and Sunnah; to revive the spirit of jibàd (holy fight), ijtihäd (legal interpretation), and tajdid (renewal); (3) to produce mujăhid (fighters), mujtahid (jurists) and muwahbid (people of tawhid/monotheist); (4) to Improve Muslims's welfare." 27 The main goal of Persatuan is stated to implement Sharia based of the al-Qur'an and Sunnah holistically (kaffah) in all aspects of life. ${ }^{28}$ In practice, Persis, especially during the period of A. Hassan was fierce and uncompromising in campaigning their goals.

Thus, aggressive approach taken by Persis in voicing their religious standpoints resulted in polemic and controversy. Traditionalist 'ulamä' reacted strongly, especially after the formation of NU (Nahdlatul Ulama), a Java-based umbrella organization for traditionalist Muslims, in 1926. Series of debate were conducted to settle the terms. Friction occurs because of disagreements originating from differing positions in the meaning and understanding of religious teachings that lead to discrepancies and disputes. ${ }^{29}$ Traditionalist Muslims accused Persis as Wahhabi, anti-local culture and tradition.

25 Howard M Federspiel, Labyrinth of Muslim Ideology: Exact Search and Struggle in the Emerging Era of the Indonesian State (1923-1957) (Jakarta: PT. Serambi Ilmu Semesta, 2004).

26 Deliar Noer, Movement of Islamic Modern in Indonesia1900-1942 (Jakarta: LP3ES, 1985), pp. 37-38.

27 Persatuan Islam, Qanun Asasi Qanun Dakbili Persatuan Islam (Bandung: Persis Press, 2005), p. 1251

28 Ibid., p. 7

29 Muhammad Ayub, "Konflik dan Integrasi: Analisis terhadap Pemahaman Persatuan Islam (PERSIS) dan Nahdhatul Ulama (NU) (Studi Kasus Masyarakat Kelurahan Mekarsari Depok Jawa Barat)," http://www.repository.uinjkt.ac.id/dspace /.../ayub\%20final.pdf accessed on 20 November 2014. 
In this context, the opinions of A Hassan occupy an important place in the discourse of religious discussion. He, along with Muhammad Natsir is known as a pioneer in the Islamic reform movement in Indonesia as well as the ideologist of the Persis movement. A. Hassan molded Muhammad Natsir's thoughts, Muhammad Isa Anshory, Abdul Kadir Hassan and more other Persis leading figures. Natsir's background and activities often depicted as the continuity of A Hassan's philosophical ideal. ${ }^{30}$

Then, Persis gave more emphasis on da'wah (propagation) and tarbiyyah (education) activities. In the case of $d a^{\prime} w a h$, Persis held a series of tablighs (preaching) in various regions. On tarbiyyah, Persis held many lectures concerning various religious issues, both for adults and youth. Around 1927, a class was held for young people who were studying at the Dutch Government secondary school. Many prominent figures in the modernist Islamic organizations such as Muhammadiyah, Sarekat Islam, and DDII spent some time to study in Persis schools. ${ }^{31}$ Persis also established a religious boarding school, similar to pesantren of its traditionalist counterparts. The Persis pesantren was originally established in 1936 located in Bandung with the main objective to train preachers. $^{32}$ In 1940 the pesantren was moved to Bangil, a region near Surabaya in East Java. Unsurprisingly, A. Hassan led this pesantren until he passed away in 1958. ${ }^{33}$ Unlike pesantren of traditionalist Muslims that mainly teaches Islamic jurisprudence based on Shafii school of law, this Persis Pesantren teach modernist view of Islamic jurisprudence. It teaches the al-Qur án, figh, hadith, ușul al-figh (Islamic legal theory), and Arabic. Unsurprisingly, Sufism is not taught. In addition to Islamic subjects, math, geography, Indonesian language and some other general subjects was also taught. ${ }^{34}$

\section{Persis Method in Islamic Law}

Islamic jurisprudence is always main feature that differentiate a Muslim group to another. Persis, being a reformist organization, differs

\footnotetext{
30 Akh Minhaji, A Hassan: Sang Ideolog Reformasi Fikih di Indonesia 1887-1958 (Jakarta: Pembela Islam, 2015)

31 Ibid.

32 Toto Suharto, Organic Community-Based Education: Pesantren Persatuan Persis 1983-1997 (Sukoharjo: Fataba Press, 2015), p. 144.

33 Federspiel, Islam and Ideology in the Emerging Indonesian State, p. 117.

34 Ibid.
} 
sharply from other traditionalist organization like Nahdlatul Ulama. Persis is seen as literalist par excellence, as embodied in its first mufti, A. Hassan. ${ }^{35}$ Surely, A. Hassan epitomizes religious standpoint of Persis as he was the mufti of that organization as well as teacher of its subsequent muftis. Born in Singapore in 1887, he was Tamil descent. He studied Islam informally when in Singapore. His father was a journalist for Islamic magazine Nur al-Islam in Singapore and also a trader. As young boy he once worked as journalist in local newspaper Utusan Melayu as an author in religious rubric which shaped his sharp mind. ${ }^{36} \mathrm{He}$ came to Indonesia as a young lad with his father for trading. He joined Persis in 1926 and soon shaped the way of religious thinking of this reformist organization.

Textual and puritanical standpoint of Persis manifests in several aspects of its legal methodology. First of all, it seeks to return to the pristine Islam by referring only to the al-Qur'an and hadith by exercising Ijtihād. While only qiyas (legal analogy) in its basic meaning is employed, A. Hassan only acknowledges Ijma' (consensus of Muslim jurists) that was reached by the companions and that was based on the al-Qur ${ }^{-} a n$ and hadith. ${ }^{37}$ In consequence, A. Hassan denies the authority of Sunni schools of law. It also denounces the inclusion of foreign elements into religious practice. Secondly, as it is reflected from A. Hassan's thought, he employs very rigid and consistent literal linguistic interpretation of the religious texts. ${ }^{38}$ This is deployed when interpreting texts of the al-Qur an and hadith. Thirdly, when dealing with the hadith, he employs rigorous hadith examination independently. Persis refuses to follow past judgment on the authoritativeness of a hadith. It does its own examination by researching the rawis (narrator/transmitter), then examining their qualification based on the books of rijal al-hadith (biography of hadith narrators) especially Mizán al-I'tidal by al-Dhahaby. If all the rawi is of the hadith are thiqah (trustworthy) or there is no desecrated narrator

35 M.B. Hooker, Indonesian Islam: Social change through contemporary fatawa (Crows Nest: Asian Studies Association of Australia in association with Allen and Unwin and University of Hawai'i Press, 2003), p. 48.

36 Federspiel, Islam and Ideology in the Emerging Indonesian State, p. 86.

37 A. Hassan, et al., Soal Jawab Tentang Berbagai Masalab Agama, part II (Bandung: Penerbit CV. Diponegoro, 2000), pp. 22-24.

38 Hooker, Indonesian Islam, p. 48. 
then the hadith may be classified into hasan or sahih according to their respective qualification. ${ }^{39}$ Thus, Persis stresses the importance of alQur'an and hadith as the sources of law and the root for further inquiry and modern research.

A. Hassan's contribution to the development of hadith literature in Indonesia is well-known which can be seen in terms of how the hadith be examined and understood. He explains his opinion about hadith in his Soal Jawab Tentang Berbagai Masalah Agama, a compilation of Persis' fatwa which he served as mufti for decades. According to him, to find out whether or not a hadith is valid, first, it is necessary to The analysis of hadith narrator is indeed very necessary to prove the validity of the hadith. In this case, A. Hassan only examined the mukbarrij (compiler of hadith) until täbi'in, because according to him, the sabäbah (companions of the prophet) were already well-known for their adalab (piety), as were the mukbarrij. ${ }^{40}$ His treatment of the matan (content/substance) of hadith follows the usual procedure of ijtihād (legal interpretation), which include linguistic analysis (such as mushtarak, 'aam, mutlaq, mujmal, and zăbir). ${ }^{41}$

However, a close examination of Persis legal methodology (turuq al-istinba $\bar{t}$ ) shows a significant shift. In a book entitled Turuq al-Istinbat: Metodologi Pengambilan Hukum Dewan Hisbah Persatuan Islam publishen in 2018, it is stated that Persis also employed qawāid fiqhiyyah (legal maxims), maslahah al-mursalah (principle of benefit), istișāb (continuity), sadd al-dāri'ah (blocking the means), and 'urf (custom). ${ }^{42}$ In addition to that, the book also allocates discussion on maqasid al-shari'ah. ${ }^{43}$ All of these shifts potentially shape contemporary Persis muftis.

\section{Misogynic Hadith According to 'Ulamā' of Persis Pesantren}

Hadith can be referred to as the report of statements or actions of the prophet or of his tacit approval or criticism of something said or

39 Hassan, Soal Jawab Tentang Berbagai Masalah Agama, pp. 434-435.

40 Ahmad Hassan, Ringkasan Islam (Bangil: Al-Muslimun, 1972), p. 17.

41 Hassan, Soal Jawab Tentang Berbagai Masalah Agama, p. 13-15.

42 Dewan Hisbah Persatuan Islam, Turuq al-Istinbat: Metodologi Pengambilan Hukum Dewan Hisbah Persatuan Islam (Bandung: Persis Pers, 2018), p. 147.

43 Ibid., pp. 81-84 
done in his presence. ${ }^{44}$ Whereas misogyny can be defined as hatred of women or something that constitutes a feeling of dislike. ${ }^{45}$ It is a philosophical doctrine that degrade the position of women. Therefore, misogynic hadith is the statements or actions or tacit approvals or criticisms narrated from The Prophet which show hatred toward women or feeling of dislike to women. From this definition, it can be concluded that there is no misogynic hadith, but there is misogynistic understanding and interpretation toward hadith.

Misogynic hadith gives rise to two contradictive opinions among 'ulama' ' of Persis pesantren in Bangil. Some of them asserts that the misogynic hadith exists, whereas others stated otherwise. ${ }^{46}$ The typological interpretation of misogynic hadith by the 'ulama' of Persis Pesantren in Bangil is both textual and contextual. The contextualist 'ulamā' who postulate the existence of misogynic hadith do not subscribe to textual interpretation. They view the misogynic hadith and such interpretation is more than textual interpretation. They believe that misogyny is not part of Islamic teaching. They agree that some hadiths do contain misogynic tendency. About such hadiths, they prefer not to use them and employ other hadiths that propagate gender equality and justice. ${ }^{47}$ In contrast, the textualist 'ulamā' of Persis Pesantren assert that there is no sabīb (sound) hadith that degrades women dignity (misogynic). What really happen is the (mis)understanding toward hadith which result in misogynic understanding. This latter opinion argues that accepting the existence of misogynic hadith is contradictory to historical fact and therefore irrelevant, because Islam elevates the status of women and not to degrades it. Therefore, a new attitude should be taken and reinterpretation of misogynistic hadith should be carried out.

\footnotetext{
44 Mahmud Ath-Thahan, Taysir Mushthalah al-Hadis (Beirut: Dar ats-Tsaqafah alIslamiyah, n.d.), p. 15.

45 A.S. Hornby, Oxford Edvanced Leaner's Dictionary of Corrent English (London: Oxford University Press, 1983), p. 541. Hater of woman means hatred towards women.

46 Interview with Umar Fanany, November 15, 2014

47 They who agree that some hadiths do contain misogynic tendency therefore they prefer not to use those hadiths and prefer hadiths that propagate gender equality and justice are Luthfie Abdullah Ismail and Umar Fanany.
} 


\section{Method and Approach in Comprehension of Misogynic Hadith}

In analyzing the misogynic hadith, 'ulamā' of Persis Pesantren In Bangil uses the comparative method. ${ }^{48}$ This method is arranged by comparing one hadith with another. Also, they compare hadith based on Qur'anic verses in the same related topic, the opinions of companions of the Prophet and Muslim jurists. To gain a thorough comprehension of the misogynic hadith, one must compare it with other reliable and authoritative sources of law. ${ }^{49}$

In addition, certain texts (of the al-Qur an and the hadith) are categorized as furü'iyyah-zanniyyah (details and relative in meaning) like some misogynic hadiths. Thus, it must be subjected under nusus usüliyyah-qat'iyyah (essential and absolute texts) and maqāid shari'ah. This assumption is supported by the opinion of 'ulama's of persis pesantren that the tabliti (analytical) method of interpretation influences the emergence of the misogynic hadith, since this method employed human reasoning in understanding the content of the hadith. The tabliti method of interpretation should be textually read and in compliance with shari'ah since its interpretation is subject to waby (revelation). This interpretation limits the use of reason in tafsir. However, since it brings reason to interpretation to a certain dgree, it is considered tafsir bi al-ra'y (rational interpretation). ${ }^{50}$

In other word, in understanding a misogynic hadith, the 'ulama' of Persis Pesantren still employ the reason but with a certain limit. The reason is that the text of the hadith is rooted from revelation. The use of the reason cannot be completely free but must be subservient to the text, especially if related to misogynic hadith. Reinterpretation of misogynic hadith is necessary, after determining the authenticity of the sanad (chain of transmitters). When the sanad is sabih (sound), then the

\footnotetext{
48 Hadiths discussed in this article is based on interview with ulama of Persis Pesantren in Bangil, East java which later are described and analyzed

49 The Ulama cite the opinion of Muhammad al-Ghazali who says that the parameter in matn analysis is conducted in 4 methods; the examination with the Quran; the examination with other hadith, the examination with historical facts, and the examination with scientific truth. Umi Aflaha, "Hermeneutika Muhammad al-Ghazali," Kurdi et al.., Hermeneutika Al-Quran \& Hadis (Yogyakarta: eLSAQ Press, 2010), pp. 354-355.

50 Al-Furqan, "Heremeneutika Hadis, Tinjauan Historis, Metode dan Aplikasi Terhadap Penafsiran Al-Quran dan Hadits," al-Adalah, 14, 1 (June 2011), pp. 69-70.
} 
matn (body/content) is sabih. The quality of sanad determines the validity of the teachings it contains and the speed with which it is to be believed and practiced. ${ }^{51}$

The approach the Persis 'ulamā' use in understanding misogynic hadith is also theological in a sense that God has absolute provision over everything. This inclination is reflected in their assumption that misogynic hadith cannot exist, even if there are hadith that textually discredit women. According to them, such circumstances are absolute provisions of God. Also, behind the precept, there is hidden wisdom which is good for humans, especially women themselves. For example; in response to gender equality, they argue that women's position is equal to men, according to their respective roles and duties. Men and women have their respective duties and obligations so that the role played is also reflecting the nature of its creation with its advantages and disadvantages as innate from birth. ${ }^{52}$

In addition to the theological approaches in understanding misogynic hadith, these 'ulamā' also uses a linguistic (metaphoric) approach, a mixture of literal interpretation and hermeneutics. The linguistic (metaphoric) approach is used to understand a misogynic hadith which judges women to be secondary creature. According to the majority of them, the hadith means a warning to men to be wise in dealing with women, not to be rude and harsh. ${ }^{53}$ Some of them understand hadith in literal meaning and some of them understand it in a combinative way between the harfiyah (literal interpretation) and the metaphoric. In current usage, this is called hermeneutic. When applied to analyze opinions of ' $\mathrm{ulama}^{-}$' in Persis Pesantren In Bangil in understanding the Misogynic hadith, it discovers both literal and phenomenological-contextual interpretation. A literal hermeneutic approach is an understanding of misogynic hadith by re-understanding

51 Syuhudi Ismail, Kaedah Kesabihan Sanad Hadis, Telaab Kritis dan Tinjauan dengan Pendekatan Ilmu Sejarah (Jakarta: Bulan Bintang, 1988), p. 5 and pp. 105-106.

52 Yunahar Ilyas, Feminisme dalam Kajian Tafsir Al-quran: Klasik dan Kontemporer (Yogyakarta: Pustaka Pelajar, 1997), pp. 61-72.

53 Nasaruddin Umar, Argumen Kesetaraan Jender Perspektif Al-Quran (Jakarta: Paramadina, 2001), p. 238. 
the meaning of the word in the text of the hadith, to find the objective meaning that is not nuanced and misogynic. ${ }^{54}$

\section{Opinions of 'Ulamā' of Persis Pesantren on Some Misogynic Hadiths}

There are several 'ulamā' of Persis Pesantren in Bangil whose views are in this article, notably Luthfie Abdullah Ismail (Principal of the Pesantren and member of Hisbah Committee), Umar Fanany (vice principal of the pesantren for academic affairs) Ahsin Lathif (coordinator for hadith teachings and the related subjects), and Bambang Priyono (vice principal for administration). They were asked about several hadiths that potentially are misogynic with mixed results; textual and contextual. Among misogynic hadiths that will be discussed in this article, there are: inappropriateness of woman to be a leader; ${ }^{55}$ Women's inferior creature and secondary importance compared to men; ${ }^{56}$ women's deficiency in religion and intelligent $;{ }^{57}$ the curse upon women who refuse to have sexual intercourse with her husband; 58 the obligation of women to prostrate herself before her husband; 59 advisability of women's prayer in the house than in the mosque; ${ }^{60}$

54 Syarifa Hasanah, "Hermeneutika Hadis Syuhudi Ismail," Kurdi, Hermeneutika AlQuran \& Hadis, pp. 373-374.

55 al-Bukhari, Shabih al-Bukhari (Semarang: Toha Putera, 1401 H/1981 M), Part VIII, p. 97. The hadith is narrated by Abu Bakrah whi said that he Prophet has said: "A nation would not excel if it authorizes women in its affairs (al-Bukhari).

56 Ibid., Part 3, volume 7 (Cairo: al-Sya'b, n.d.), p. 34. The hadith is narrated from Abu Hurayrah from the Prophet He says: read women kindly, for woman was created from a bent rib, and the most crooked part of the rib is the top part, so treat women kindly (al-Bukhari)

57 Ibid., Kitab al-Haidh, hadith no. 293 and kitab al-zakah, hadith No. 1369. Hadith from Abu Said al-Khudry, he says, Rasulullah PBUH comes out and says: "I have not seen anyone with reductions in mind and religion than women."

58 Al-Bukhari, Shabihu'l Bukhari, kitab Bad'u'l Khalq (Beirut: Dar Ibn Katsir, n.d), vol. 3, p. 1182.

59 Abu Dawud, Sunan Abu Dawud, part 1 vol. 2, p. 244. The hadith is transmitted from Abu Hurayrah from the Prophet PBUH, he says: "If I were to command anyone to prostrate to anyone other than Allah, I would have commanded women to prostrate to their husbands.

60 Ibid., vol. 1, p. 156 and Ahmad bin Hanbal vol. 4, p. 371. The hadith is transmitted by Abu Dawud with full translation is: "Your prayer in your room is better for you than your prayer in your courtyard and your prayer in your courtyard is better for you 
women as the majority inhabitants of hell; ${ }^{61}$ restriction of women mobility out of her house without her mahram; ${ }^{62}$ the lack of women's right for divorce; ${ }^{63}$ seductive nature of women; ${ }^{64}$ women status as awrab. ${ }^{65}$

The understanding of "ulamā' of Persis Pesantren toward hadith "the prohibition of female leadership" leads to two types of interpretation; textual and contextual. Those who understand the hadith textually view female leadership as something beyond the ambit of her qudrat (aptitude or destiny). Men are the ones that God gives the capacity to lead women, while the female is to be led. The Hadith on the prohibition of female leadership must be properly observed. When women are leaders, their leadership will lead to destruction. ${ }^{66}$ On the other hand, those who understand the hadith contextually do not prohibit women from entering various professions such as professors,

than your praying in your house, and your prayer in your house is better for you than your prayer in my mosque."

61 Al-Bukhary, Shabih al-Bukhary, p. 34. The hadith is narrated by Abu Said al-Khudry, he says: Rasulullah PBUH came out on Id al-Adha or Id al-Fitr, "He passed by the women and said; O women! Give charity, for I have seen that you form the majority of the people of Hell.

62 Ibid., vol. 1, p. 712, vol. 2, p. 1174 and vol. 3, p. 2164, Muslim, vol. 2, p. 978. The hadith is narrated by Ibn Abbas Ra. Heard the Prophet said: A man and a woman must not court, No woman should travel except with a mahram." A man said: O Messenger of Allah, I want to go out with such-and-such an army, but my wife wants to go for Hajj. He said: "Go home and perform hajj with her."

63 Ibid., Talaq no. 4867, 4868 and 4869; al-Nasa'i, talaq no. 3409 and Ibn Majah, talaq no. 2046. The hadith is narrated by Abu Asma from Thawban he said, The Prophet said: "Any woman asks her husband for a divorce, for no reason, then the smell of paradise is forbidden for her".

${ }^{64}$ Muslim, Shabih Muslim, Vol. 2, p. 1021. The hadith is narrated by Jabir, that the Prophet Saw a women then he went home to see his wife and did what he needed to do with her, afterwards, he said to his companions that the woman who was in front him was in shape of a devil. So when one of you sees a woman, he should come to his wife, for that will repel what he feels in his heart.

65 Al-Tirmidzi, Sunan al-Tirmidzi, Vol. 2, p. 259. The hadith is narrated by Abdullah from the Prophet, he said: "The woman is 'awrah. When she goes outside (the house), the devil welcomes her."

66 Interview with Umar Fanany, October 15 , 2019. The hadith is narrated by Abu Hurayrah, He said that The Prophet said: "Never will succeed such a nation as makes a woman their ruler." see al-Bukhari, Shahib al-Bukhari (Semarang: Toha Putra, 1401/1981M), Vol. 7, p. 97. 
doctors, businessmen, ministers, judges, and other occupations on condition that they should always observe Islamic law. ${ }^{67}$

The textual understanding was also adopted by the 'ulama' ' of Persis Pesantren In Bangil toward hadith of "Women are Secondary Creatures." The majority of them accept the hadith "women are created from men's ribs." Some have openly acknowledged that women are subordinates of men because of the dominance aspect in their emotional capacity. Whereas some of them understood the hadith as a command to do good to women. With the understanding of the distinguished character of men and women so that the word "crooked" was not be understood in the negative connotation. The Hadith on "less religious and intelligent" of women were adopted by the majority of the 'ulama' of Persis Pesantren in Bangil whose meaning is still relevant today. According to them, the hadith meant that women could not worship at certain times, due to menstrual period. Whereas the "lack of female intellect" is reflected in the testimony of women which value half of the testimony of men. The hadiths are specific and conditional that they have to be understood contextually. ${ }^{68}$

Later on, the hadith which states that "angels of God will curse a wife if she does not fulfill her husband's sexual desire" 69 is also understood by them both textually and contextually. Textual understanding is asserted by a minority of those who see it from a husband's point of view. The hadith contains the command that the relationship between husband and wife should be based on seeking the blessing of Allah and worship. A wife is obliged to obey her husband. If the husband asks his wife nicely and politely, as well as the wife's situation is loose, then there should not be a refusal. Such an understanding is powerful about the position of men over women. To avoid such an effect, it must be understood contextually. According to them, there must be a mutual understanding between husband and

\footnotetext{
67 Interview with Umar Fanany on October 15, 2019. This view is in line with opinion of Indonesian Muslim feminist, like Husein Muhammad who says that the hadith is informative, not legal legitimacy. Therefore, the hadith cannot be understood as it is, but has to be discerned from its essence and not to be generalized for all cases. This hadith is specific for the Persians. See, Husein Muhammad, Fiqh Perempuan: Refleksi Kiai atas Wacana Agama dan Gender (Yogyakarta: LKiS, 2007), p. 202.

68 Interview with Umar Fanany and Bambang Priyono, October 15, 2019.

69 Al-Bukhari, Shabibu'l Bukhari, kitab Bad'u'l Khalq, Vol. 3 (Beirut: Dar Ibn Katsir, n.d.), p. 1182
} 
wife who can understand one other's situation. Since men are sexually aroused quite easily, they should be gentle in asking for sexual intercourse with their wives. A wife should be affectionate in responding to her husband's desire, even when she is busy. ${ }^{70}$

As for the hadith about "it is advisable for women to perform prayer at home," there are two opinions about it. First, the hadith is understood contextually by comparing the hadiths that addressed the same issue and by scrutinizing the woman's situation and condition in performing congregational prayers at mosque and her commitment to fulfilling her duties as a mother and wife. According to Yusuf Qardhawi, ${ }^{71}$ the first steps to be taken are to amass all sabīb (sound) hadiths on the subject and then inspect its meaning to determine whether it is mutashabih (multi interpretable) or mubkam (fixed meaning), associating the mutlaq (unspecified meaning) with the muqayyad (specific meaning) and interpreting the general (' $\mathrm{amm}$ ) with the particular $(k h \overline{a s}) .{ }^{72}$ This step has to be taken because many hadiths indicated that women attended prayers together with the Messenger of Allah (peace be upon him) at the mosque, performed prayers behind him, and the prophet did not prohibit it. ${ }^{73}$ The Messenger of Allah (peace be upon him) only allowed women to attend mosque at night in safe environment with several cautions. They should not to use perfume, avoid men's flirtation, not to put on make-up nor dress up, and not to neglect their household duties. Secondly, textual interpretation of hadith that women better performed prayers at home because this hadith is sound and that the jamáab (congregational) prayer at mosque is not an obligation for women. ${ }^{74}$ This literal reading of the hadith assumes that women are not advisable for prayer at mosque.

70 al-Mubârakfûrî, Tuhfat al-Ahwadżi bi Syarh Jami' al-Turmudži, vol. 4, pp. 324-325.

71 Kurdi, Hermeneutika Al-Qur'an dan Hadis, p. 439.

72 The opinion of Yusuf Qardawi is presented here because it is identical with those stated by the ulama of Persis pesantren in contextually interpreting the hadith urging women to perform prayers at home by comparing similar hadith and involving situation and condition of women in performing prayer in the mosque and their commitment to do household works.

${ }^{73}$ For instance, a hadith narrated by Ibn Umar, he heard the Prophet said: "When your wives ask permission to do prayer in mosque, give them permission" (Muslim). Muslim, Shabih Muslim, vol. 1 (Beirut: Maktabah Dar Ihyai al-Kutub al-'Arabiyyah, n.d.), p. 187.

74 Interview with Umar Fanany, November 15, 2014. 
The hadiths of the Messenger of Allah (may peace be upon him) that "women are to prostate to her husband" can be scrutinized in the aspect of sanad and matn of the hadith. On the sanad aspect, the hadith is narrated by many of companions of the prophet, ${ }^{75}$ although no sanad is under valid qualification, there is hasan (good) narration by Abu Hurairah. Based on matn of hadith, it is an acceptable hadith except for a few sentences in the hadith which are rejected by the scholars. However, some assert that the hadith is impracticable and there is no need to look for reasons to justify it. According to them, the hadith is invalid because prostration to creatures is considered an apostasy and therefore not allowed. The expression of the Prophet in the presumption word of "law" (if) does not mean command, but rather a metaphoric description that indicates importance of fulfilling husband's rights. ${ }^{76}$

Content wise, this prostration hadith is viewed by some 'ulamā' of Persis Pesantren In Bangil against the al-Qur'an which assert the equality between husbands and wife. ${ }^{77}$ However, this opinion is rejected by some others because the al-Qur an signifies the superiority of the husband upon the wife. ${ }^{78}$ The authority of the man (husband) is not used to oppress the wife and so the hadith must be understood in accordance with the al-Qur'an's instructions to avoid misunderstandings, falsification, and wrongdoing because the alQur'an guide to achieve certainty and justice. ${ }^{79}$ Therefore, the understanding of the Prophet's hadith should be in line with the alQur an. An understanding of a hadith that is contrary to the al-Qur'an may occur because the hadith is weak (zaif) or its interpretation is incorrect or the contradiction is arbitrary. Therefore, the hadith which is contrary to the Quranic principle must be casted off as long as no interpretation is acceptable. ${ }^{80}$ Thus, their understanding of the hadith represents the typology of normative textual understanding.

\footnotetext{
75 They are Abu Hurayrah, Qays bin Sa'd, Anas bin Malik, Muadz bin Jabal, Abdullah bin Abi Aufa, and Aisha

76 Interview with Umar Fanany, November 14, 2014.

77 Interview with Bambang Priyono, November 14, 2014.

78 The Quran Chapter 2: 228

79 The Quran Chapter 6: 115

80 Aflaha, "Hermeneutika Hadis Muhammad Al-Ghazali, pp. 353-356.
} 
Similarly, the hadith that "most of hell's inhabitants are women because of their ungratefulness toward her husbands" is perceived differently among the "ulamā' of Persis Pesantren in Bangil. Some accept it as it is without any reservation. As such, the hadith has authentic sanad and narrated from five companions of the prophet, so that its authenticity is undisputed. However, according to some others, the hadith must be read along with other hadith so that the meaning can be fully comprehended. So, it may be interpreted textually while comprehending the meaning of the hadith by comparing it with other hadith. The next step is to assemble the sahih hadiths in the same subject followed by linking the mutashabbih content to the mubkam, the mutlaq with muqayyad and interpreting the general with the particular. ${ }^{81}$

However, some 'ulamā' understood this hadith contextually. According to them, most women are put into hell not because of their gender but because of their disobedience. The hadith does not insinuate hatred towards women. If the hadith is read comprehensively then it will be understood that it reflects the Prophet's attention and care to women. The Prophet warned the women of the sins that were often committed. Besides, the Prophet also provided advice and a way for women to escape the torment of hell.

As for the hadith about 'women are awrah', it is understood by the 'ulamā' of Persis Pesantren In Bangil as a woman who arouse men's sexual inclination toward her. ${ }^{82}$ This line of understanding of the hadith is similar to what as understood by mainstream of hadith scholars. ${ }^{83}$ Therefore, women are advised to remain at home to maintain their aurat and to keep out of men's sexual desire. God has established positions, portions, and rules for men and women in this way, for Allah knows best and the best for His creatures. ${ }^{84}$ The view that these hadiths are misogynic is simply the depiction of dissatisfaction with what Islam has prescribed for them. ${ }^{85}$ Thus, some 'ulamā' of Persis pesantren read the hadith textually.

\footnotetext{
81 Ibid.

82 Interview with Umar Fanany, October 15, 2019.

83 Ibid.

84 Interview with Bambang Priyono, October 15, 2019.

85 Ibid.
} 
The Persis Pesantren in Bangil agrees that what is meant by 'women as seducer' as illustrated in the sentence that "women are, the embodiment of demon" is not to equate women with demons. The Hadith explains that women are naturally desired by men, both from the front side or back. So the word 'devil' is only a form of metaphor of the attractiveness of women that can lead men to do something that is forbidden by God. The Hadith also contains a warning that men should be careful, and indirectly encourage women not to play an active role in public spaces. ${ }^{86}$ From this understanding, it appears that the interpretation applied based on the metaphorical (majär) approach.

Indeed, many of the Prophet's hadith uses majaz to express its meaning impressively. The Prophet is an Arabic native speaker who mastered balaghah (Arabic belles lettres) and which his expressions were part of revelation. The majaz phrase is seen by balaghah as a more lasting eloquence than an expression that is in the ordinary narration. The meaning of the word which is in the form of majaz either lughawi, 'aqli, isti'arah, kinayah is not to be understood directly but through the indicator that supplements the meaning either textual and contextual. In this context, the understanding of majaz word is a necessity. If the text is not to be understood metaphorically, then it will deviate from the intended meaning. ${ }^{87}$

The hadith that the wife must be accompanied by her male mubrim (close relative) while traveling understood by the Persis Pesantren in Bangil as an effort to protect women from various possibilities and does not mean that women do not have freedom and independence. Many factors will endanger a woman when she is traveling alone. This type of reading shows that the hadith should be understood in metaphoric understanding and that understanding the hadith only in literal meaning would not provide useful meaning. This approach strives to find the objective meaning of the hadith which is desired by the Prophet. According to Schleimacher, ${ }^{88}$ there are steps to be taken through the historical-objective Reconstruction approach, discussing a hadith through comprehending the language as a whole system. the

86 Interview with Umar Fanany, October 15, 2019.

87 The interview with Umar Fanany on October 15, 2014 indicates similarity with the opinion of Muhammad al-Ghazali as explained by Aflaha, "Heremeutika Hadis Muhammad Al-Ghazali, pp. 357-358.

88 Interview with Umar Fanany, October 15, 2014. 
criticism upon the matn of hadith can be used relies on the accuracy of the ratio (association), matn expressions, test the validity of the composition and structure of the language of matn, and testing the coherence level of the concept contained in the formula of matn hadith.

In regard to the "hadith about women should not file for divorce," it is understood in at least two views by the "ulama' of Persis Pesantren in Bangil. Some of them believe that Islam gives the right of the wife to file a divorce if there is a valid reason that allows it. ${ }^{89}$ Some others argue that 'women can submit kbul' by returning the dowry to husband. Therefore, the woman can file for divorce, just as a woman can file $k b u l^{\prime}$. Of course, the reason for the submission of the khulu' must be based on the justified reasons under Shari'ah'. If the reason does not excusable, then divorce or kbulu' will not be granted..$^{90}$

From the discussion, there are three categories of misogynic hadith from the perspective of 'ulamā' of Persis Pesantren in Bangil. There are two hadiths that all 'ulama' ' of Persis pesantren agree upon. They are the hadith that women are awrah (private parts) and the hadith that women are seducers. There are also hadiths on which the majority of them agree upon, with minority dissenting opinion. This type of hadith is the hadith stating the secondary status of women and the hadith asserting women's deficient intellect and religion. The last category is the hadiths that are heavily contested among them. The hadiths include a hadith on women leadership, the hadith on curse of angels for wives who are reluctant to fulfil their husbands sexual needs, the hadith that women should do prayers at home; the hadith that commands women to prostrate to their husbands; the hadith that women are most inhabitants of hell, and the hadith which prohibits women from asking for divorce.

\section{Conclusion}

From the description above it is concluded that the majority 'ulamā' of Persis Pesantren In Bangil believe in the existence of misogynic hadith, while the minority of them in view of the non-

89 The hadith is narrated by Abu Asma from Thawban he said, The Prophet said: "Any woman asks her husband for a divorce, for no reason, then the smell of paradise is forbidden for her." See Al-Bukhari, Shabih al-Bukhari.

90 Wahbah al-Zuhayli, al-Fiqh al-Islamy wa Adillatubu, Vol. VII (Damascus: Dar al-Fikr, 1989), p. 496. 
existence of misogynic hadith, only the misogynistic understandings of hadith that vitiate women right that is occurring. 'Ulama' ${ }^{\prime}$ and teachers of Persis Pesantren, who understand the misogynic hadith apply the comparative method of theological, linguistic and hermeneutic approaches both literal and phenomenal-contextual hermeneutics. Whereas those who assume the non-existence read the hadith textually. The hadiths which are understood as misogynistic are: "the prohibition of women's leadership, women's deficiency in religion and intelligence, the curse of angels for wives who refuse to entertain her husbands' sexual desire, the advisability of women prayer at home, majority of women are in hell, women as secondary creatures, male traveling company for women are interpreted contextually by most teachers of Persis Pesantren In Bangil and textually by some others. Meanwhile, the hadith related to the command of women to prostrate to their husbands" is understood critically by them from the aspects of sanad and matn, without neglecting the message of the al-Qur'- an. The hadith about women as awrah is understood textually. While the hadith about women as flirters is understood metaphorically to grasp the meaning of the text of the hadith. As for the understanding of the hadith on the prohibition of the wife asking for a divorce, it must be read in intertextual interpretation.

Textual and traditional understanding of misogynic hadith by ignoring asbāb al-wurüd (the circumstance when the hadith once revealed by the prophet), uslub (language expression), the method of which the Messenger of Allah presenting the hadith, and partial interpretation of hadith will only result in out of context understanding. In consequence of the traditional textual reading of misogynic hadith, it will produce an attitude that degrades the dignity of women. The contextual interpretation of the Persis Pesantren In Bangil towards misogynic hadith seems different from the patterns of interpretation applied by the mainstream reformists which is textual. This means that there has been a change in the interpretation patterns among the 'ulamá' and teachers of Persis Pesantren who are categorized as reformers from textual to contextual, especially in interpreting misogynic hadith. ${ }^{91}$

91 Ahmad Fudhaili, Perempuan Di Lembaran Suci; Kritik Atas Hadis-hadis Shabih (Jakarta: Kementerian Agama RI, 2012), p. 137. 
Contextual interpretation on misogynic hadith as it is expressed by 'ulamā' of Persis pesantren contradicts an assumption that the reformists tend to be textual. However, this hypothesis needs to be examined. Furthermore, the contextual interpretation of misogynic hadith affects the reformulation of Islamic law, thus creating opportunities for women to participate in public role in various phases of life including their own families. As a result, women who have expertise in a particular field become excellent figure, either in the society, politics, and bureaucracy.

In contrast, the textual interpretation of misogynic hadith makes the role of women reduced in several areas of social life, particularly in domestic life which ideally is built together. The reason is that because each husband and wife have an important role according to their respective characters. Sometimes, the resentment and dispute arise in domestic life due to different tasks and roles. Men work outside the home, while most women work inside the home. This case does not mean unfair treatment, but a complementary existence. In other words, the textual interpretation of misogynic hadiths makes it difficult for women to realize their outmost potential. []

\section{References}

\section{Books and Articles}

A. Hassan, et al. Soal Jawab Tentang Berbagai Masalab Agama, part II. Bandung: Penerbit CV. Diponegoro, 2000.

A. Hassan. "Muqaddimah Ilmu Hadis dan Ushūl Fiqh". Tarjamah Bulüg al-Maram. Bandung: CV Penerbit Diponegoro, 2001.

A. Hassan. Ringkasan Islam. Bangil: Al-Muslimun, 1972.

A. Hassan. Tarjamah Bulûgul Marâm. Bandung: CV Penerbit Diponegoro, 2002.

A.S. Hornby. Oxford Advanced Learner's Dictionary of Corrent English. London: Oxford University Press, 1983.

Aflaha, Umi. "Hermeneutika Hadis Muhammad al-Ghazali". Kurdi et al. Hermeneutika al-Quran dan Hadis. Yogyakarta: eLSAQ Press, 2010.

al-Alusi, Ruh al-Ma'ani fi Tafsir al-Quran al-Adzim wa al-Sab'I al-Matsani. n.p.: Dar al-Fir, n.d. 
al-Bukhari, Shahih al-Bukhari, vol. 7 and 8. Semarang: Toha Putera, $1401 \mathrm{H} / 1981 \mathrm{M}$.

al-Ghazali, Muhammad. Al-Sunnah al-Nabawiyyah baina Abl al-Figh wa Abl al-Hadis. Kairo: Hadza Dinuna, 1989.

al-Nasa'i, Abu Abdurrahkam bin Syuaib. Sunan al-nasai. Egypt: Musthafa al-bab al-halabi, 1964.

al-Tirmidzi, Muhammad Isa bin Saurah. Sunan al-Tirmidzi. Mesir: Musthafa al-bab al-Halaby, n.d.

Al-Zahabi, Sayyid Husein. al-Israiliyyat fi al-Tafsir wa al-Hadiths. Damascus: Lajnah al-Nasyr fi Dar al-Iman, 1985.

Al-Zamakhsyari. al-Kasysyaf 'an Haqaiq al_Tanzil wa Uyun al-Aqawil fi Wujub al-Ta'wil. Beirut: Dar al-Fikr, 1977.

Atabik, Noor al-Din. "Pendekatan Kaum Modernis Terhadap Studi Hadis”. https://jurnalulumulhadis.blogspot.com/ 2014/ 02/pendekatan-kaum-modernis-terhadap-studi.html/accessed on 1 January 2020.

Ayub, Muhammad. "Konflik dan Integrasi: Analisis terhadap Pemahaman Persatuan Islam (PERSIS) dan Nahdhatul 'ulamā' (NU) (Studi Kasus Masyarakat Kelurahan Mekarsari Depok Jawa Barat). http://www. repository.uinjk.t.ac.id/dspace /.../ayub\%20final.pdf accessed on 20 November 2014.

bin Hanbal, Ahmad. Musnad al-Imam Ahmad bin Hanbal. Beirut: Dar alFikr, n.d.

Dawud, al-Sijastani Sulaiman bin al-Asy' at Abu. Sunan Abu Dawnd. Vol. 1 and 2. Mesir: Musthafa al-bab al-Halabi, 1952.

Federspiel, Howard M. Labirin Ideologi Muslim: Pencarian dan Pergulatan Persis di Era Kemunculan Negara Indonesia (1923-1957). Jakarta: PT. Serambi Ilmu Semesta, 2004.

Federspiel, Howard M. Persatuan Islam: Pembaharuan Islam Indonesia Abad XX. Transl. by Yudian W. Asmin and Afandi Mochtar. Yogyakarta: Gadjah Mada, 2002.

Federspiel, Howard M. The Usage of Tradition of The Prophet in Contemporary Indonesia. Monograph in Southeast Asian Studies, Program for SAS, Arizona State University, 1993. 
Hardiman, F. Kritik Ideologis; Menyingkap Kepentingan Pengetabuan Bersama Jurgen Habermas. Yogyakarta: Penerbit Buku Baik, 2004.

Hasanah, Syarifa. "Hermeneutika Hadis Syuhudi Ismail". Kurdi et al. Hermeneutika Al-Quran \& Hadis. Yogyakarta: elSAQ Press, 2010.

Hornby, A.S, Oxford Edvanced Leaner's Dictionary of Corrent English. London: Oxford University Press, n.d.

Ilyas, Yunahar. Feminisme dalam Kajian Tafsir Alquran Klasik dan Kontemporer. Yogyakarta: Pustaka Pelajar, 1997.

Imron Rosyadi. "PERSIS Board of Legal Determination Method". http: // www. publicationilmiah.ums.ac.id/ handle/123456789/906. Accessed on November 20, 2014.

Ismail, M. Syuhudi. Hadis Nabi yang Tekstual dan Kontekstual. Jakarta: Bulan Bintang, 1994.

Kholil, Sayid Ahmad. Dirasat fi Alquran. Mesir: Dar al-Ma'arif, n.d.

Khon, Abdul Madjid. Takhrij dan Metode Memahami Hadis. Jakarta: Amzah, 2014.

Khozin, Ahmad. Pemahaman Hadis Misoginis pada Kitab Uqudul Lujayn Pondok Pesantren An Nur Klego Candirejo Tambang Kab. Semarang. Unpublished MA Thesis, IAIN Salatiga, 2017

Kurdi et al. Hermeneutika Al-Qur'an dan Hadis. Yogyakarta: eLSAQ Press, 2010.

Martin, Richard C "Understanding The al-Qur'an in Textual and Contextual". Jurnal of History of Religion, 21, 4 (May 1982).

Mas'udi, Masdar F. Islam dan Hak-bak Reproduksi Perempuan: Dialog Fiqh Pemberdayaan. Bandung: Mizan, 2000.

Mernisi, Fatima. Perempuan dalam Islam. Jakarta: Penerbit Pustaka, 1994.

Mernisi, Fatima. Seks dan Kekuasaan. Yogyakarta: Penerbit Al Fikr, 1975.

Muhammad, KH. Husein. Fiqh Perempuan: Refleksi Kiai atas Wacana Agama dan Gender. Yogyakarta: LKiS, 2007.

Nasaruddin, Umar. Argumen Kesetaraan Jender, Perspektif Al-Quran. Jakarta: Paramadina, 2001.

Rofiq, Muhamad. "Memahami Hadis-Hadis Misoginis Perspektif Maqasid Syariah: Studi Hadis yang Menyamakan Antara Keledai, Anjing dan Perempuan". Ilmu-Ilmu Ushuluddin, 16, 1 (April 2015). 
Rosyadi, Imron. "Metode Penetapan Hukum Dewan Hisbah PERSIS". http://www. Publikasi ilmiah.ums.ac.id/handle/ 123456789/906. Accessed on 20 November 2014.

Rosyadi, Imron. "PERSIS Board of Legal Determination Method". http: // www.publicationilmiah.ums.ac.id/ handle/123456789/906. Accessed on 20 November 2014.

Syamsuddin, Sahiron. Hermeneutika Al-quran \& Hadis. Yogyakarta: eLSAQ Press, 2010.

Wahid, Ramli Abdul. "Perkembangan Kajian Hadis di Indonesia (Studi Tokoh dan Ormas Islam)". Kamaruddin Amin, et al. Quo Vadis Islamic Studies in Indonesia? (Current Trends and Future Challenges) (Makassar: UIN Alauddin Makassar, 2006.

Wildan, Dadan, Da'i Yang Politikus. Bandung: Rosda, 1997. 